\title{
LEADERSHIP ROLES IN MANAGING EDUCATION IN CRISES: THE CASE OF KENYA DURING COVID-19 PANDEMIC
}

\author{
Rosemary Wahu Mbogo ${ }^{i}$ \\ Dean of Education, Arts and Social Sciences, \\ Africa International University, \\ P.O. BOX $24686-00502$, \\ Nairobi, Kenya
}

\begin{abstract}
:
Covid-19, a disease caused by a novel coronavirus (SARS-CoV-2) was first reported in Wuhan, China, in December 2019 and in Kenya in March 2020. In Kenya, the Covid-19 pandemic has brought to light some unknown talents among the stakeholders at different levels. The economic sector has had manufacturing potential for goods, and from mass media reports, this has been demonstrated through production of Personal Protective Equipment (PPEs), ventilators and innovations in technology in the creation of apps such as the Linda App for contact tracing and Gumzo, a video conferencing app. Similarly, the education sector has also demonstrated potential for adaptation in some situations. For example, after all institutions of learning were closed to prevent the spread of coronavirus in March 2020, many universities have continued learning through Online, Distance and E-learning (ODEL) platforms, and some have even conducted virtual graduations. Others like Kenyatta University have reported innovations such as development of ventilators and modified testing swabs for Covid-19. This is admirable despite numerous limitations of internet accessibilities and other shortcomings. This remarkable achievement has been possible due to semi-autonomy in the university education sector, where Senates are given the right and power, by the Education Act, to make autonomous decisions for their universities which are regulated and monitored using the standards and regulations set by the Commission of University Education (CUE). However, other levels of the education sector do not have this autonomy and have had to depend on the ministry of education for guidance. On $8^{\text {th }}$ July 2020, the ministry of education announced the result of a consultative meeting with stakeholders, to postpone the reopening of schools to January 2021. This was due to the rising cases of corona virus infections in May and June, steeping the infection curve, expected to reach the peak by November and to have flattened by January 2021 (Magoha, 2020). However, what surprised many was the additional and unforeseen announcement that all basic education students (apart from standard 8 and form 4 examination candidates whose details were not clarified) will
\end{abstract}

i Correspondence: email rosemarywmbogo@gmail.com 
repeat their current class levels in 2021. The pronouncement caused anxiety and has attracted mixed reactions from various stakeholders. The purpose of this paper is therefore to explain the leadership decisions made by the ministry of education analyze their impact on basic education and propose possible ways for educational leaders and administrators, community leaders and volunteers to facilitate home-based education during the Covid-19 pandemic. This should be done with a goal for progression and promotion of students to the next class level when the 2020 syllabus is eventually covered. The study method utilized desktop literature research where interactions with educational leaders, scholars and practitioners were used to investigate threats and opportunities in managing education during crises.

Keywords: Covid-19, Coronavirus, crises management, educational leadership

\section{Introduction}

Crises are inevitable since time immemorial and crises' management is necessary for human life to survive and thrive. According to Zamoum and Gorpe (2018):

"What constitutes a crisis is not easily agreed . . upon however, despite lack of clarity, there are specific conditions of crises in the crisis literature. For example, crisis situations share six characteristics which are . . rare, significant, high impact, ambiguous, urgent and involve high stakes ... Crisis involves a period of discontinuity, a situation where the core values of the organization/system are under threat, and this requires critical decisionmaking. There is a destabilizing effect of the organization and its stakeholders and escalation of one or more issues, errors or procedures are expected in this period ..."

Crises can be caused by disasters, emergencies, and pandemics, among other maladies. While crises vary in scope, their tendency to become global has been on the increase in the last two decades with people being more connected globally. The advent of globalization with its increase in international travel and the growth of the technology sector have presented the world with humongous opportunities and threats, simultaneously.

In December 2019, a novel coronavirus (SARS-CoV-2) was detected in Wuhan, China and soon its rate of infection leading to fatality was on the rise. The fatalities were due to a complex respiratory syndrome named Covid-19. Within three months, the virus had spread to over 100 nations in the world and to 213 by July 2020 (Worldometer, 2020; WHO, 2020). The Covid-19 pandemic has paralyzed many human activities while at the same time providing numerous opportunities for innovation. The outcomes of the impact, whether negative or positive, depend on leadership and personal initiatives in the society. This paper seeks to explain the decision made by the ministry of education directing that students will repeat their current (2020) class levels when schools reopen in the year 2021. The paper will also highlight potential challenges and threats the 
decision induces to basic education, including: Sustainable Development Goals (SDG) and Kenya's vision 2030; Children's Rights, Human and Material Resources, Curriculum Implementation (Schooling versus Learning), Crises Management Cycle and Historical Lessons in Managing Education during Pandemics. In addition, the paper will propose a way forward in addressing the needs of basic education learners by enhancing homebased education.

\section{Discussion}

\subsection{Leadership Decisions and Basic Education during the Covid-19 Pandemic}

The first coronavirus infection case in Kenya was reported on $12^{\text {th }}$ March 2020, from a Kenyan who travelled from the United States through the United Kingdom. By that time, many had died in China, Italy, Spain, United States of America and parts of Middle East and Asia, and these countries had taken containment measures such as social distancing, sanitization protocols and quarantine (WHO, 2020). Having learnt from them, Kenya's government quickly announced similar containment measures and by $13^{\text {th }}$ March, the president ordered schools to close, followed by colleges and universities a few days later. The president also instructed employers to allow staff to work from home. For continuing education, the president promised the use of television and radio to broadcast basic education. Google balloons were also to be launched country-wide to enhance working from home and virtual learning. The president also launched a fundraiser to help mitigate the foreseen social-economic needs caused by imminent disruption of the economy. There was much energy and enthusiasm to help Kenyans fight the pandemic, flatten the infection curve while protecting lives and livelihoods. The management of the fund was placed in the hands of the private sector who would give Kenyan's confidence that the donations would reach the expected benefactors. Money and resources in kind began to trickle and in three months the fund had reached KES. 2.8 billion (Kenya Covid Fund, 2020). Churches and other organizations also collected funds to help the needy (Hearth, 2020; Campbell, 2020).

Education resources began to flow including in digital format, such as by the United Nations (Department of Global Communications, 2020) and the Kenya Institute of Curriculum Development (KICD) at the Kenya Education Cloud (kec.ac.ke). The institute also scaled up the national broadcast programs in partnership with the Kenya Broadcast Corporation (Kabasa, 2020).

As the virus continued to spread through community transmission, the government had to issue more stringent containment measures such as continued sanitization, wearing of masks, mass testing and contact tracing, curfews, cessation of movement out of and into cities and counties where the rate of spread was worrying; such as Kilifi, Nairobi and Mandera (Kiragu, 2020).

While these measures helped in slowing the rate of infections in the first two months (see Figure 1), the impact of the containment measures on the economy and the education sector became worrying. Impatient Kenyan's began to appeal through social 
media for the reopening of the country to allow movement. There was a clear disregard to the laid down protocols as media reported cases of people bribing the police to be allowed to move to and from the restricted areas and also various groups were caught partying beyond curfew hours and without observing social distancing.

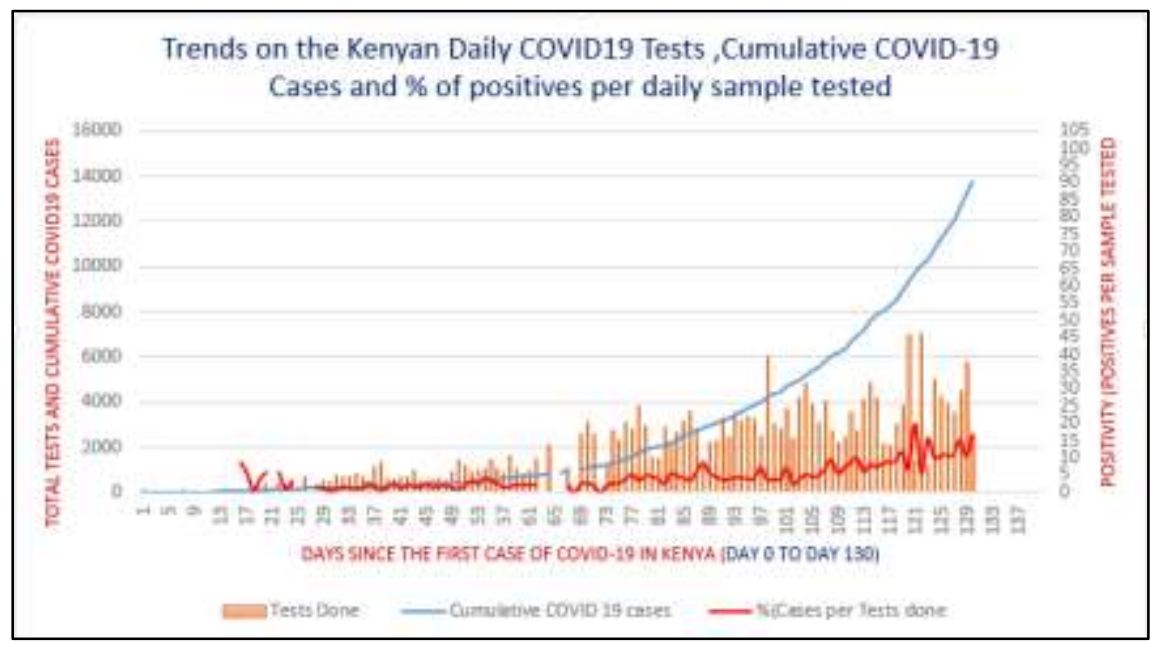

(Source: Ministry of Health, 2020)

Moreover, as people lost jobs and could not pay rent, they were desperate to leave urban areas to join their rural folk in a bid for survival. As Figure 1 shows, the spread of the virus began to escalate after 60 days. This pushed the president to task various committees representing different sectors to come up with guidelines for reopening and or phased out reopening of various sectors of the economy such as churches, schools and the tourism industry, within a month from $7^{\text {th }}$ June 2020. The religious sector submitted their guidelines and on $6^{\text {th }}$ July 2020 the government allowed churches to reopen beginning $12^{\text {th }}$ July with strict guidelines, including temperature checks, sanitization protocols, social distancing protocols and congregation gatherings of not more than 100 people at a time. Other sectors were also allowed to reopen under similar guidelines congruent to their industry.

However, the education sector recommended the reopening of basic education schools to be pushed to January 2021 when the transmission rate of the virus is expected to have passed the peak and the infection rated curve flattened, and when schools will be better prepared with infrastructure to receive students within containment protocols. Tertiary institutions and universities were allowed to reopen in September 2020 while adhering to the set guidelines. While this move was applauded as necessary in protecting children from infection, what shocked many stakeholders was the declaration by the Cabinet Secretary of Education through the media that the pandemic virtually wiped out the 2020 academic year and that schools will likely reopen in January 2021 (Magoha, $7^{\text {th }}$ July, 2020) this being the source of the contention. Up to this point, many parents and students expected a phased-out reopening in September 2020 as per the president's initial directive. The CS explained that the consultative meeting representing various stakeholders had reached consensus to reopen in January 2021 and that students (Grade 
1-4, Standard 5-7 and Form 1-3) would repeat their current classes. The ministry did not announce when Standard 8 and Form 4 examinations would be administered, though they made it clear it will not be in 2020. It could be possible, in the spirit of a phased-out reopening, that the candidates will reopen first to sit for their examinations and others later, but for the purpose of this paper, assumption is made that January 2021 reopening is meant for all grades, since no guidance have been given to examination candidates on how they could prepare for their final examinations during the pandemic.

Since the pronouncement, stakeholders have responded variably, with many affirming the government for prioritizing the safety of students and teachers, while many still were exasperated that their children will have to repeat their classes and loose the academic year. Parents, especially those with examination candidates, have been investing during the pandemic in their children's education by paying for virtual learning, or by buying additional learning materials, or by supervising the learning of the children through the television and radio broadcasts, and other resources with hope of progression. Citizen TV, for example, had interviews of some parents expressing concern that their efforts were being rendered futile as their children would lose motivation to keep up with schoolwork; other parents reported they had just bought new school uniform for their fast-growing children and complained that they will have to shop again in 2021, in spite of the biting economic realities from loss of income, businesses and jobs, during the pandemic; others still complained that they had paid school fees for a whole year and wondered what would happen. Students also expressed disappointment at the pronouncement, especially those who have been vigilantly expecting to sit for their final examinations this year. Their dreams to be done with primary and high school, join colleges and university, or move on to the next class level have been procrastinated. While the Cabinet Secretary quickly responded to the latter and issued a directive to school heads to refund parents second and third term 2020 fees that was paid in advance, the matter of repeating classes remains a challenge. This could not have been foreseen especially because the government outlawed class repetition according to Section 35 of the Basic Education Act, No 14 of 2013. Hence, the decree of repeating class has puzzled many since the pronouncement. This decision raises various issues that need to be considered in this paper.

\subsection{Achievement of the Global Sustainable Development Goals (SDGs) and Kenya's Vision 2030}

The member states of the United Nations adopted seventeen Sustainable Development Goals $4^{\text {th }}$ (SDG) for action by 2030. The fourth goal is about provision of quality education, that is, to ensure quality education that is accessible, inclusive, relevant, equitable, comprehensible, and practicable. It is education that reduces illiteracy level especially in reading and mathematics which implies development of competencies that promote lifelong learning opportunities for all (United Nations, 2015). The ministry of education reiterated the virtues of accessibility and equitability as key drivers for the decision to have learners repeat the academic year, given the polarities existing in the Kenyan society 
between the rich and the poor. The decision to have the year repeated however does not in any way fix the problem, but rather exacerbates it. This is because, Firstly, repeating has implications on the effort students, especially the poor, will make to keep up with schoolwork throughout. Without progression, most students will be lax for the rest of the year 2020 academically as they wait for reopening. Although it is already known that children from poor families, in the villages and slums of Kenya have largely not been continuing with learning, the knowledge that they will repeat their classes in 2021 will aggravate the situation. In the meantime, their counterparts from able parents will continue learning, even albeit with declined enthusiasm, as they have been doing. Secondly, it is not clear how long the pandemic will remain as a threat and whether the curve will have flattened by January 2021. In case the infection rate is still high or situations of second waves happen as predicted in the developing countries (Maragakis, 2020), and if there will be no approved vaccine, reopening of schools may even be later than estimated, causing further disruptions. Thirdly, many students and parents will possibly slip into lethargy because of the decision which is likely to disrupt optimism towards students' achievement, progression and retention in school.

In addition to SDG's, Kenya's vision 2030 expects education and training to play a key role in the achievement of our development goals. "The Social Pillar in Kenya Vision 2030 aims at creating a comprehensive, equitable and just society based on democratic ideals. Under this pillar, education and training is expected to be the principle catalyst towards realization of Vision 2030" (Kenya Vision 2018-2030, p. 5). Having students repeat the year may widen further the rich-poor education divide as those with resources will provide their children with opportunities to continue with learning. Many of the rich and middle class may have improved economic status out of the economic stimulus from the government and reduced expenditure due to social distancing. They also comprehend the value for education for their children. Contrariwise, the poor may end up losing out in academics and may not make any effort to cover schoolwork as they redirect their efforts to survival due to the household's lost income avenues and higher food prices. Evidently, this will make the poor to lag behind their counterparts even more when they eventually reopen school and the ripple effects of this gap will be felt in years to come. This situation will therefore continue to polarize the society many years and decades to come. Therefore, postponement of the academic year is clearly not progressive and may hamper the fulfillment of vision 2030 with regards to national development.

\subsection{National and International Guidelines on Children's Rights}

The Kenyan constitution provides for basic education as a basic right for children. Basic education - from pre-school to high school (day schooling) entails passing on of knowledge, skills, and values from one generation to another. In Kenya, this education is based on two types of curriculum - the Competence Based Curriculum (CBC) from preschool to primary school grade 1-4 and the 8-4-4 system from standard 5-8 and high school from form 1-4. The curriculum implementation cycle requires assessment as a major component because the "Effectiveness of the curriculum and its implementation requires 
assessment that is based on the curriculum taught in the classroom; is linked directly to what has been taught; and is conducted on a regular basis to closely monitor students 'progress toward curricular benchmarks" (Pearsoncmg, p. 7). The postponement of the year disrupts continuity and is essentially a denial of children's rights to quality education. While all understand that the Covid-19 pandemic is an emergency that was not called for, efforts should have been made to provide continuity in learning by adapting to the situations. Adaptation implies continuing with the essentials of education such as the curriculum content but adjusting the activities, and methods of teaching and assessment within new learning environments. This will introduce a new normal rather than waiting for learning to continue conventionally within institutions and the usual implementation approaches (the traditional normal).

It seems contradictory that the ministry of education, through Kenya Institute of Curriculum Development (KICD), continues to offer remote or distance learning content through radio, television and online, and yet with no intention to assess the students' learning and provide progression to the next class levels. This is, therefore, a departure from national and international commitment to the provision of quality education as a basic right for children.

\subsection{Wastage of Substantive Material and Human Resources}

As the Cabinet Secretary of Education announced the nullity of the year 2020 for basic education, he assured Kenyans that the ministry will continue to offer learning through distance education platforms. Since the commencement of the quarantine season, television and radio programs have been provided by the Kenya Institute of Curriculum Development (KICD), which also hosts a website - Kenya Education Cloud (kec.ac.ke) where digital content of the Kenya Curriculum can be accessed in audio and videos. Clearly, the issue of accessibility to those who cannot access internet or mass media communication could have been addressed using other learning approaches, including correspondence, because the government has invested in road networks that has made the courier business robust in the country and parcels can be delivered to any part of the country through Kenya's Express Mail Service (EMS) of Kenya's postal services and other providers in the private sector.

Moreover, efforts of the government in preparing all the content to be more accessible does not match the decision to declare the year 2020 as lost in learning. The decision does not match the ongoing diligence to train teachers to use technology and teach virtually, that has been scaled up since the closure of schools. For example, training for Science, Technology, Engineering and Math (STEM) subjects by the Center for Mathematics, Science and Technology in Africa (CEMASTIA). Internationally, there are useful courses for free in international platforms such as the Massive Open Online Courses (MOOCs). The United Nations and the World Bank have also provided websites with information on various learning resources. Kenyan educationists in the diaspora have created websites providing free learning materials such as EduMonitor. Several international companies have learning management systems that can be accessed for free. 
These include Moodle, Google classrooms and even Teams, in certain conditions, and these can be used to host the Kenya curriculum which is already available in digital content. Moreover, the local private sector has also played a role in helping the education sector. For example, tele-companies, like Safaricom, have offered data bundles for education at reduced prices, programs such as Viusasa Mwalimu have been provided for students.

These national and international resources, efforts and interventions only need educational leadership and administration to help in coordinating logistics and guiding in implementation of an emergency 2020 learning program with the goal for implementing and assessing learning for progression. As Burns notes:

"There's no "right" distance education choice right now. Every country has to choose the best medium or a mix of media based on access, technical infrastructure, content, the ability to adapt this content to the appropriate distance education medium or mix of media-and make learning opportunities available to students as quickly as possible." (Burns, 2020)

In addition to wastage of material resources, the wastage in human resources is glaringly disturbing. The teaching workforce is the biggest among civil servants, with basic education teachers employed by the Teachers Service Commission (TSC) totaling 320,000 teachers. According to the government, this workforce will continue to receive salaries for the rest of the year (a total of 10 months) even without adequate input in their profession. This defeats the directive of working at home given by the president after the closure of schools. Relatedly, there have been reports from the media that teachers are reporting depression in various hospitals, and while some attribute it to salary delays, containment measures such as social distancing and cessation of movement are depressive due to disruptions in lifestyles. Additionally, life satisfaction is not just a factor of income, but also of engagement in worthwhile job-related ventures (Mbogo, 2016; Ohide \& Mbogo, 2017). There is also an added risk of extended fatigue due to extended schools' closure, which may result to insurmountable levels of "post-vacation-syndrome" where employees experience challenges in adapting back to their routine (Psychologypedia, 2019).

There are over 300,000 trained but unemployed teachers in Kenya (according to TSC), who can engage in teaching during the pandemic season through the government's Covid-19 economic stimulus package, as interns. Private schools (both charity-based and business oriented) also employ over 200,000 trained teachers. The media has reported that several of these private schools, just like other businesses, are on the verge of collapsing and some have already collapsed, closed, and diverted their premises to other ventures. In the spirit of Public-Private Partnerships (PPPs) entrenched in the Kenya Public Private Partnership act, the government could involve the private players to help in this time of the pandemic. This is even more necessary as public schools must decongest to handle the pandemic. Similar to the government's partnership with universities where government sponsored students are placed into private universities, 
the government can begin to engage the private sector offering basic education, both for continuing with learning for all Kenyan children and continue partnership even after reopening.

Additionally, the number of students in universities and teacher's training colleges who are waiting for graduation are also in thousands. Some of these only need to do their teaching practice to complete their degrees. They and their colleagues who have competed could be useful during this time. There are retired teachers who are still active and would be willing to give back to the community if called upon, within the containment measures. Finally, there are many untrained teachers also teaching in the informal sector and other professionals out of work who would wish to teach. With necessary training and induction, these can be useful in contexts that lack sufficient trained teachers. Therefore, it is possible to organize the potential teaching workforce to assist in home-based, community-based, and distance learning for all basic education students in Kenya and still make it to promote students to the next level when the syllabus for the year is covered.

\subsection{Home-Based Education}

There is a difference between schooling and learning. Schooling is primarily a phenomenon of the middle ages where learning, primarily a household affair, was institutionalized (Oduor, 2019). The growth of formal schooling has been undergoing various transformations in curriculum development and implementation that have led to reconsideration of home-based education by many stakeholders. In the West, schooling as we know it began in the $16^{\text {th }}$ century and got rooted in the $19^{\text {th }}$ century after the advent of industrialization (Gary, 2008). Before this time, children learnt life skills through the home and trade skills through observing adults such as in apprenticeship. This was similar to Kenya and Africa, where schools were introduced by the missionaries and later by the colonial masters in the $19^{\text {th }}$ and $20^{\text {th }}$ centuries; before then, children learnt from home and from community-based systems of formal learning (Mbogo, 2015). In the African setting this system of learning was well organized by community leaders. In our current Covid-19 scenario, we have children used to schooling now at home for an extended period; expecting them to learn meaningful knowledge, skills and values without coordinating activities is more of wishful thinking than realistic planning. Studies in Kenya show that only $30-40 \%$ of parents are usually involved in assisting their children with homework with correlations found between parents' level of education, socio-economic status and being correlated to levels of involvement, students' retention or student's academic performance (Kimathi, 2014; Echaune, Ndiku \& Sang, 2015).

Notwithstanding parents' limitations, learning does not need institutionalized schooling to happen. This implies that the government and all community leaders need to consider coordinated learning in the confines induced by social distancing rules. Home-based learning needs to be considered and brought to the fore.

Schooling is primarily a phenomenon of the middle ages and has been undergoing various transformations that have led to reconsideration of home-based education by 
many stakeholders. With regards to academic performance, studies as earlier noted have shown that children who are home-schooled can thrive in academic achievement similarly or even better than their counterparts in schools. According to Ray (2020):

- The home-educated typically score 15 to 30 percentile points above public-school students on standardized academic achievement tests. (The public school average is the $50^{\text {th }}$ percentile; scores range from 1 to 99.) A 2015 study found Black homeschool students to be scoring 23 to 42 percentile points above Black public school students.

- Homeschool students score above average on achievement tests regardless of their parents' level of formal education or their family's household income.

- Whether homeschool parents were ever certified teachers is not related to their children's academic achievement.

- Degree of state control and regulation of homeschooling is not related to academic achievement.

- Home-educated students typically score above average on the SAT and ACT tests that colleges consider for admissions.

- Homeschool students are increasingly being actively recruited by colleges. (Ray, 2020)

Although the study was not done in Kenya, the home-based education has also been on the rise. Due to the frustrations many parents encountered because of the 8-4-4 system for over a decade, and before the launch of the Competency based Curriculum (CBC), many resulted to home schooling and other systems of education. The homeschooling movement has been growing, as clearly seen by many websites that offer advertise their homeschooling ventures, both online and face to face (Nairobi Home School, Nairobi Online Academy, HLSDA and many others). Although data is not available Google search gives an estimate of homeschoolers to be 500-1000 families in Kenya. Some of the homeschooled children in Kenya have already been admitted to Kenyan universities for some years. One academic staff explains:

I first met a home-schooled child in the mid-1990s. She was the daughter of friends of mine and also neighbours in Nairobi's Buruburu Estate. At the age of five, she was already confident and articulate. This began to dispel my doubts about Home-schooling. About ten years ago, I was requested to help look at some research papers written by some home-schooled high school finalists using a different curriculum from 8-4-4. I was pleasantly surprised to find out that unlike their counterparts in the 8-4-4 system, they were considerably well acquainted with library research and writing: they intelligently cited various books and articles using footnotes, and meticulously laid out their lists of references in a manner reminiscent of what is expected of first-year university students in Kenya! I have also had an opportunity to facilitate a "Thinking Skills" course for five home-schooled high school students, and was impressed by their confidence, clarity of thought and expression, and keenness to learn. (Oduor, 2019)

It is possible to harness the experiences of parents and educators who have done or are doing homeschooling to help others in the current crisis both to in teaching and in 
the administration of home-based education. These can work along all other human resources enumerated earlier in this paper.

\subsection{Curriculum Rigidity}

Evidently, it seems that the Kenyan curriculum has not been primarily a problem of content, activities or learning materials, but a big problem in rigidity, both administration and assessment methods. In terms of administration, educational leaders and teachers rigidly follow documented guidelines, which are just meant to be guidelines to develop a robust learning environment and not laws cast on brick and mortar. Hence, curriculum implementation continues to cultivate a severely competitive learning environment where children's cognitive abilities are elevated above other facets of life. This is more so evident in assessment where Kenya continues to run a British Colonial examination model whose goal was to eliminate some from continuity, mostly due to limited resources and infrastructure. Ranking performance of students against their peers remains prevalent. Rewards are given to academic achievers at the expense of other talents. This examination-based model (Mackatiani, 2017) has condemned many children as failures, and many continue to grow as adults with a failure mentality. Only a few have been able to break from that and continue to thrive and usually through some interventions. While the government has made great strides to change that narrative through the new Competence Based Curriculum (CBC), the decision for learners to repeat their class levels in 2021 casts shadows on the promises of the new curriculum. Since the CBC purports to integrate activities that require parental involvement, it is not clear why the ministry of education could not coordinate continued and assessable learning at home. The Covid-19 emergency therefore presents a great opportunity to employ new methods of curriculum implementation and assessment.

Collaborative methods of learning, research and project-based learning, community service and other activities that enhance learning could be incorporated (Gillies, 2016; Fakomogbon \& Bolaji, 2017). Special continuous tests and examinations could also be administered by using the readily available human, material technological resources. The final grade to promote students could be decided using multifaceted and integrated assessment methods that can minimize examination phobia among students. Depending on type of content, learning can be assessed through alternative methods such as open book examinations, hands-on-projects, oral examinations, and other creative assignments which can be assessed using rubrics and portfolios. For example, students taking agriculture can build garden farms for assessment, home science, students can do some work at home, science projects can be integrated with home activities, and research work related to Covid-19 can be assessed to earn a grade. Such innovative approaches can help demystify examinations and reduce stress. If necessary, usual examinations could be administered sometime after reopening, covering the period students were at home, after revisions with their teachers. If these measures are taken, it may be possible to salvage the remaining months of 2020 and ensure progression of students. At the very least, the term that was cut short by three weeks could be completed and an additional 
one term is still doable in the remaining months before reopening. With smaller classes envisaged in 2021 due to social distancing rules related to the pandemic, it may be possible to catch up with curriculum plans in shorter durations than usually possible with larger classes - depending on how much the government and other stakeholders will invest in school infrastructure and new teacher employment. Research shows smaller classes improve learning due to ability for teachers to manage student's behavior and hence avoiding interruptions and the ability for teacher to interact more personally to students (Finn, Pannozzo, \& Achilles, 2003). This would imply that if schools open in January 2021, students and teachers could be handling term 3 of 2020 and a new year could be launched in April.

\section{The Crises Management Cycle}

Along the Covid-19 crises, Kenya has been hit by swarms of locusts since November 2019 to March of 2020, and flash floods that have killed over 200 people between April and May 2020 (Smith, 2020). Additionally, tribal fights among pockets of Kenyan communities, for example, Narok and Marsabit have been reported by the media between March and June 2020. These situations, and heighted politically instigated anxiety caused by verbal and physical political wars by rival politicians (eKenyan July, 23 News) have compounded the challenges facing children and adolescents. Education leaders and administrators are supposed to be in the frontline offering solutions for learning within the limitations encountered due to the crises. Crisis management is not an event, but a process which requires ongoing generation of plans for progress during the crises, with ongoing assessment of successes and failures to enable improvement. This process is comprised of four phases:

"Phase one is mitigation and prevention, which addresses what schools . . can do to reduce or eliminate risk to life and property. Phase two focuses on preparedness and the process of planning for the worst-case scenario. Phase three is devoted to response steps taken during a crisis. During phase four (sic), recovery, attention is focused on restoring the learning and teaching environment after a crisis." (Practical Information on Crisis Planning, 2004, p. 5)

The goal of a crisis management team is to restore normalcy as soon as possible. The decision to have students repeat their class levels in 2021 seems to be a huge leap to the end of a crisis cycle, without giving much room to review the status quo according to emerging knowledge. The decision also seems to have overlooked scientific data that is available.

According to the data shown in Table 1, the current statistics show that fatalities among children and young adults are low: 
Table 1: Distribution of Case Fatalities by Age and Sex

\begin{tabular}{|l|c|c|}
\hline Age Range in Year & Total Male and Female & Percentage \\
\hline $0-9$ & 4 & 1 \\
\hline $10-19$ & 2 & 1 \\
\hline $20-29$ & 7 & 2 \\
\hline $30-30$ & 29 & 11 \\
\hline $40-49$ & 50 & 20 \\
\hline $50-59$ & 53 & 21 \\
\hline 60 and Above & 115 & 44 \\
\hline
\end{tabular}

The data in Table 1 indicates that fatalities among children below 20 years of age, who are of basic education age, have recorded the least fatalities of Covid-19. This is congruent to what has been shown in the rest of the world (Centers for Disease Control and Prevention, 2020). This irrefutable data all over the world should not be overlooked and should implicate decision-making on education. The data clearly shows that basic education, whose majority of students are 4-18 years need not be grounded by Covid-19. It is possible to use the human resources of the adults with least fatality rates to continue with education, especially in the slum areas and urban areas where the younger demographics are based.

Data on the spread of the virus also has much to tell. The virus in now in Kenya's 44 counties and so, 3 counties so far have no known case. According to the ministry of health's daily situation report of $23^{\text {rd }}$ July, the average infection rate in Kenya is $31.1 \%$ per 100,000 population. However, the rate is different from county to county: six counties have over $30 \%$ infection rate, five have $10-20 \%$, seven others $5-7 \%$, thirteen have $2-4 \%$, and thirteen have $1 \%$ and less. Only two counties have an infection rate of over $100 \%$. Given that the rate of infection is very low in some counties, it is evident that we should not have a national closure of schools. The use of data in an appropriate manner would have called for a phased-out closure.

Perhaps, one can understand the decision of the government at the beginning of the pandemic in Kenya when no one had an idea of how the novel virus would spread and affect Kenyans. However, with the available national data and the new knowledge emerging regarding the novel coronavirus, infection management, recovery and fatalities rates of Covid-19 patients, the ministry of education can consider measures for continued learning - that is quality learning with assessment for the purpose of progression to the classes. According to the technical note for dealing with Covid-19 emergency by the Interagency Network for Education in Emergencies (INEE), decisions made to respond to needs of a crisis' acute phase will influence those of the recovery phase. It will be important to keep this perspective during the acute phase; decisions that are made to sustain learning opportunities during the acute phase should foster actions that will need to happen in the recovery phase. For example, activities to ensure continuity of learning during the acute phase should not result in learning opportunities that represent a parallel system to the formal one. Rather, they should be structured and communicated about as temporary measures, recognizing that some might be appropriately 
institutionalized depending on what the recovery phase reveals about a possible "new normal". However, some of the modalities of education service delivery-such as distance learning-that might be critical during the acute phase can be explored as post-crisis options for reaching marginalized students $(\mathrm{MoH}, 2020)$.

The Cabinet Secretary insinuated that decisions can be revised based on emerging situation. Therefore, continuous assessment of the Covid-19 status and the ongoing negative impact on students out of school could inform the ministry of education to revise the decision that students will repeat classes in 2021. Moreover, community leaders, educators and other stakeholder can take responsibility to ensure both safety from the virus and progress in home-based education, at least to catch up with a part of the 2020 academic year and ensure students are motivated to focus on assessable learning.

\subsection{Socio-Economic Effects}

The pronouncement of the year 2020 as a "lost year" academically seems to be inconsiderate of serious socio-economic drawbacks soon. First, pre-school students will be affected because it is not feasible for school facilities to handle two streams of class one pupils as new intakes exceed 1 million pupils. This implies that either pre-school pupil will have to equally repeat their class levels or school in shifts. Second, universities and tertiary institutions will not have an intake of high school graduates in 2021, implying there will be significant shortage of revenue from tuition for a few years. Third, there may be delayed supply of important skills in some careers whose intakes are restricted to only a few students, such as in the Sciences, Technology, Engineering and Mathematics (STEM) programs due to lack of university graduates around 2025-6 academic years. This implies there will be gaps in human resource in some sectors of our economy. Fourth, monetary resources will be wasted as parents had paid fees for first term 2020. Repeating the year implies parents pay for first term again in 2021 and many will need to purchase new uniform for their growing children. Considering lost jobs and businesses, this is punitive to all and especially needy parents and it amounts to wastage of resources that could have been directed to another area of households' needs. Most of the government resources invested in basic schools in January to mid-March 2020, will also be wasted instead of contributing to the development of the education sector. Fifth, the rate of school dropouts will spike due to various reasons such as teenage pregnancy, students' achievement of adult status and academic achievement loss as discussed in the next section.

\subsection{Achievement of Adult Status}

In addition to teenage pregnancy, there are students who may rationalize that they have acquired the adult status at 18 years of age and therefore reduced motivation to go back to school. This is especially the case because the Kenya school system has not been generally learner friendly due to corporal punishment which is still prevalent among teachers (Mweru, 2010; Matofari, 2019) and examination phobia which has been a major cause of students' unrest in Kenya (National Crime Research Center, 2017). Moreover, 
academic achievement has been on the decline in the last three years with more than $30 \%$ of high school students scoring D+ and below. Even though the results have been appraised by some to imply success in mitigating against examination malpractices, the high number of low scores (usually associated with failure) unravels a bigger problem in the Kenya curriculum. A heavily exam-oriented curriculum has been shown to hamper learning (Mackatiani, 2017). The dropout rate due to achievement of adult age will become a new normal for several years, since all students will take one more year to complete school, pushing the end of school age to 19 years instead of the current 18 years. Many young people usually look forward to achieving adult status so that they may be allowed to pursue their aspirations. In essence, the crisis posed by the forced class repeat and loss of an academic year is going to disrupt lives and futures of this generation in many ways.

\subsection{Academic Achievement Loss}

The rate of academic achievement (or learning) loss, usually common due to school absenteeism, school holiday breaks or emergency closures will be a big challenge. A study projecting potential losses for the Covid-19 six-month' closure of US schools based on data related to summer achievement losses and students' absenteeism, and the relationship between the loss and rate of recovery after return to school provides useful insights. The researchers found that:

"Students will likely (a) not have grown as much during the truncated 2019-2020 academic year and (b) will likely lose more of those gains due to extended time out of school. Based on our projections, students will return in fall 2020 with approximately $63-68 \%$ of the learning gains in reading relative to a typical school year and with $37-50 \%$ of the learning gains in math. In some grades, students may come back close to a full year behind in math. While such projections may reinforce the worst fears of educators and parents, we should note that they do not factor in the home schooling and online instruction that students may currently be receiving." (Kuhfeld, et. al, 2020, p. 23)

Given such projections for the US, there is a reason for Kenya to be concerned about the achievement of its children. The effects the extended school closure and lack of a well-coordinated learning for almost 10 months by the time schools reopen (assuming reopening in January 2020) are humongous. For example, students' learning abilities are likely to be hampered with and recovery may take longer. This will be disadvantageous to students and parents if nothing is done to have a well-coordinated continuity in learning in 2020.

\subsection{Historical Lessons of Education Management in Pandemics}

The Covid-19 pandemic has elevated curiosity among many to understand how the world has handled pandemics in the past. There is numerous information about how pandemics such as influenza, Ebola and others were managed and even specifically the 
impact and management of education. There are lessons to learn from the management of the Spanish Flu pandemic of 1918 due to its global scope and significance in the current global pandemic. In the US, some schools were not closed while others closed for up to 84 days, inclusive of the weekends. No learning was provided by the government for students during the time of closures. However, one city was noted for innovation during a time of need:

"Los Angeles stood alone in establishing mail-in correspondence courses for students in higher grade levels. In that city, public educators appeared to work well with other officials, in large part because they were given leeway to design approaches to municipally mandated school closures. The city created mail-in homework modules for high school students so that they could complete assignments at home. In addition, during this "enforced vacation," teacher courses were set up at the State Normal School, and approximately 1,500 teachers took classes to expand their subject knowledge and pedagogical skills. Thus, Los Angeles offers an interesting model for contemporary schools interested in creating Internet-ready study materials or valuable professional activities for instructors in the advent of school closure." (pp. w1073, w1075)

This is a big lesson for the world today and for Kenya in particular. We cannot afford to watch 2020 wasted, 100 years after the Spanish flu. With better health care systems, even in Kenya compared to the world those days, and all the existing technological advances that enable learning through Online, Distance and E-learning (ODEL), and with a very robust postal and courier system that can reach all students in any corner of Kenya, the government can marshal resources to salvage the plight of Kenyan children in learning during the Covid-19 pandemic. Moreover, data from the 2019 census comes in quite handy in offering solutions during this time of need. This will be a lesson for posterity, for one day, future generations will be looking at how educational administrators and government managed education and other sectors during this pandemic. Lessons of the past, both global and local, can enrich our responses.

\section{Conclusion}

This paper has explained the decision made by education leaders regarding the reopening of schools in January 2021 and the surprising decree that students will repeat their current class levels then. While the goal is about containing the spread the novel coronavirus, potential challenges and threats to the education sector have been discussed. These include: hampering the accomplishment of the Sustainable Development Goals (SDGs) and the Kenya's Vision 2030, apparent violation of the basic rights of children, wastage of material and human resources, misappropriation of crisis management theory, institutionalization of education, curriculum rigidity and socio-economic effects. The government, educational leaders and administrators, community leaders, and all 
Kenyans who are passionate about the welfare of the Kenya children need to rally together to ensure continuity in quality education. Given the current data on the spread and impact of covid-19, there is hope that Kenyans can salvage the basic education sector and eventually improve the welfare of the children. Since Kenya still has some months to go by the expected timing of reopening of schools, the educational leadership has a window to intervene.

The Cabinet Secretary of Education indicated that decisions already made can be reviewed based on data and advice from the ministry of health, there is hope that guided learning will resume with progression in mind. There is still room of ensuring continuity of meaningful learning which needs to be assessed with a view to promote the students to the next level after covering the syllabus of the year 2020. While this may not happen in January 2021, it could be feasible in the first quarter of the year or so since the academic calendar does not have to be strictly a January to November affair. Education solutions that are provided need to consider the five elements of a curriculum cycle: assessment of needs, formulation of goals and objectives, selection of content and activities, selection of methods, and evaluation. Any efforts being given through the government or private stakeholders need to continuously undertake periodic assessment and evaluation to determine and address emerging needs during the pandemic. This needs to be done with a goal to promote students to the next level, even if not within the usual calendar dates, that is, even mid-year in 2021. Failure to do that would imply wastage of enormous resources and catalyzation of numerous sociological, economic, cultural, psychological, and physiological challenges in the society.

As the government works with various stakeholders, leaders and administrators at macro and micro levels of education need to take initiative to advise, coordinate and supervise efforts geared to implementing and improving home-based education during the Covid-19 pandemic. There are numerous resources accessible to facilitate meaningful learning among students of all ages. Ongoing training of teachers and students to acquire new skills needed should be enhanced alongside guidance and counseling, economic relief, containment measures and other needed interventions.

\section{References}

Adams, C. M., View, P., \& Kritsonis, W. A. (2020). An analysis of secondary schools' crisis management preparedness: National implications. https://files.eric.ed.gov/fulltext/ED491991.pdf

Burns, M. (April, 2020). School, interrupted: 4 options for distance education to continue teaching during COVID-19. Global Partnership for Education, Education Development Center. https://www.globalpartnership.org/blog/

Campbell, B. (July, 2020). African Enterprise COVID-19 response, Kenya. 
Center for Disease Control and Prevention. (2020). Coronavirus disease 2019 in children - United States, February 12-April 2, 2020. CDCP, 69(14), 422-426. https://www.cdc.gov/mmwr/volumes/69/wr/mm6914e4.htm

Christianity Today. https://christiantoday.com.au/news/african-enterprise-covid-19response-kenya.html)

Department of Global Communications. (2020). Education and COVID-19: UN helps children continue their learninghttps://www.un.org/en/coronavirus/educationand-covid-19-un-helps-children-worldwide-continue-their-learning))

Echaune, M., Ndiku, J. M., \& Sang, A. (2015). Parental Involvement in Homework and Primary School Academic Performance in Kenya. Journal of Education and Practice $6(9), 46-53$.

Fakomogbon, M. A., \& Bolaji, H. O. (2017). Effects of collaborative learning styles on performance of students in a ubiquitous collaborative mobile learning environment. Contemporary Educational Technology, 8(3), 268-279. https://files.eric.ed.gov/fulltext/EJ1148599.pdf

Finn, J., Pannozzo, G., \& Achilles, C. (2003). The "why's" of class size: Student behavior in small classes. Review of Educational Research, 73(3), 321-368. Retrieved July 25, 2020, from www.jstor.org/stable/3516038).

Gary, P. (August, 2008). A brief history of education. To understand schools, we must view them in historical perspective. https://www.psychologytoday.com/us/blog/freedomlearn/200808/brief-history-education

Gillies, R. M. (2016). Cooperative Learning: Review of Research and Practice. Australian Journal of Teacher Education, 41(3), DOI: 10.14221/ajte.2016v41n3.3. https://files.eric.ed.gov/fulltext/EJ1096789.pdf

Hearth, K. (June, 2020). COVID-19 cases climb in Kenya; Christians respond to community needs. Mission Network News https://www.mnnonline.org/news/covid-19-casesclimb-in-kenya-christians-respond-to-community-needs/

Kabasa, E. (March 19, 2020). KBC partners with KICD to broadcast school programs https://www.kbc.co.ke/kbc-partners-with-kicd-to-broadcast-school-programs/)

Kenya Covid Fund, 2020, https://www.kenyacovidfund.co.ke/

Kenya Vision 2030. Medium term plan, education and training, 2013-2018, Towards a Globally Competitive and Prosperous Kenya. http://www.jkuat.ac.ke/directorates/dipca/wpcontent/uploads/2015/07/Education-and-Training-MTP2.pdf

Kimathi, H. K. (2014). Parental involvement in primary standard three pupils' reading at home in Igembe South Constituency, Meru County, Kenya. Kenyatta University PhD.

https://irlibrary.ku.ac.ke/bitstream/handle/123456789/12101/Parental\%20involvement\%20i $\mathrm{n} \% 20$ primary.....pdf; sequence $=1$

Kiragu, John (2020). Improving Contact tracing in Kenya: An Overview https://kenyahealthsystems.org/2020/07/21/improving-contact-tracing-in-kenyaan-overview/ 
Kuhfeld, M., Soland, J.,Tarasawa, B., Johnson, A., Ruzek, E., \& Liu, J. (2020). Projecting the potential impacts of COVID-19 school closures on academic achievement. (EdWorkingPaper: 20-226). Retrieved from Annenberg Institute at Brown University: https://doi.org/10.26300/cdrv-yw05

Mackatiani, C. I. (2017). Influence of examinations-oriented approaches on quality education in primary schools in Kenya. Journal of Education and Practice, 8(14), 51, https://files.eric.ed.gov/fulltext/EJ1143881.pdf

Magoha, G. (2020). Schools to reopen in January 2021. Digital Citizen

Maragakis, L. L. (2020). First and second waves of coronavirus. https://www.hopkinsmedicine.org/health/conditions-and-diseases/coronavirus/

Matofari, F. N. (2019). Teachers' and Students' Support for Corporal Punishment-A Practice Outlawed by the Government of Kenya. DOI: 10.1177/0886260519877949. https://pubmed.ncbi.nlm.nih.gov/31603021/

Mbogo, R. W. (2015). Historical Factors for Church's Role in Holistic Community Development in East Africa. Journal of Developing Countries Studies. 5(21): 169-176. ISSN 2225-0565.

Mbogo, R. W. (2016). The perceptions of distance education personnel of the relationship between work conditions and their job satisfaction in Kenya's Christian higher education. British Journal of Education 4(4), 42-52. ISSN 2055-0227.

Ministry of Health. (2020). COVID-19 outbreak in Kenya: Daily situation report - 127.

Mweru, M. (2010). Why are Kenyan teachers still using corporal punishment eight years after a ban on corporal punishment? https://doi.org/10.1002/car.1121

National Crime Research Center. (2017). Research issue brief into secondary schools' arson crisis in Kenya. https://www.bing.com/search?q=k\&form=EDGEAR\&qs=HS\&cvid=63d7fec0ae1c4 5018f01faefd95b3fde\&cc $=$ US\&setlang $=$ en-US\&plvar $=0$

Oduor, R. M. J. (2019). Keep It in the Family: A Case for Homeschooling in Kenya. Retrieved from: https://www.theelephant.info/ideas/2019/08/15/keep-it-in-thefamily-a-case-for-homeschooling-in-kenya/

Alhayah, D. F. O., \& Mbogo, R. W. (2017). Effect of Teachers' Own Perception of their Profession on Job Satisfaction and Performance in the Private Primary Schools in Yei Town, South Sudan. IRA International Journal of Education and Multidisciplinary Studies, 7(3), 235-239. doi: http://dx.doi.org/10.21013/jems.

Pearsibpmg. (n. d.). Components of curriculum implementation. Chapter 1, pp. 4-14. https://ptgmedia.pearsoncmg.com/images/9780137034833/downloads/Hoover_C h_1_p3_14.pdf

Practical information on crisis planning: A guide for schools and communities. (2004). Retrieved Oct. 20, 2005, from ed.gov Web site: http://www.ed.gov/admins/lead/safety/crisisplanning.doc.

Psychologypedia. (March, 2019). Post-Vacation Syndrome: Trauma of returning to routine. https://psychologypedia.org/post-vacation-syndrome-trauma-ofreturning-to-routine/ 
Ray, B. (2020). Research Facts on Homeschooling, Homeschool Fast Facts. National Home Education Research Institute. https://www.nheri.org/research-facts-onhomeschooling/

Smith, E. (2020). Coronavirus, floods and locust swarms: Kenya is fighting a 'triple whammy' of crises. https://www.cnbc.com/2020/05/18/coronavirus-floods-andlocusts-kenyas-triple-whammy-of-crises.html).

WHO. (2020). https://www.who.int/emergencies/diseases/novel-coronavirus2019/situation- reports)

Worldometer. (2020). https://www.worldometers.info/coronavirus/countries-wherecoronavirus has-spread/).

Zamoum, K., \& Gorpe, T. S. (2018). Crisis management: A historical and conceptual approach for a better understanding of today's crises, crisis management - Theory and practice, DOI: 10.5772/intechopen.76198. Available from: https://www.intechopen.com/books/ 

to copy, distribute, transmit or adapt the article content, providing a proper, prominent and unambiguous attribution to the authors in a manner that makes clear that the materials are being reused under permission of a Creative Commons License. Views, opinions and conclusions expressed in this research article are views, opinions and conclusions of the author(s). Open Access Publishing Group and European Journal of Education Studies shall not be responsible or answerable for any loss, damage or liability caused in relation to/arising out of conflicts of interest, copyright violations and inappropriate or inaccurate use of any kind content related or integrated into the research work. All the published works are meeting the Open Access Publishing requirements and can be freely accessed, shared, modified, distributed and used in educational, commercial and non-commercial purposes under a Creative Commons Attribution 4.0 International License (CC BY 4.0). 